\title{
Concentrations of Gaseous Elemental Mercury in the Atmosphere of a Mediterranean Coastal Site in Greece
}

\author{
Christiana Polyzou*, Glykeria Loupa, Spyridon Rapsomanikis
}

Laboratory of Atmospheric Pollution and of Control Engineering of Atmospheric Pollutants, Department of Environmental Engineering, Faculty of Engineering, Democritus University of Thrace, 67100 Xanthi, Greece; E-Mails:cpolizou@env.duth.gr; gloupa@env.duth.gr; rapso@env.duth.gr

* Correspondence: Christiana Polyzou; E-Mail: cpolizou@env.duth.gr

Academic Editor: Zed Rengel

\author{
Adv Environ Eng Res \\ 2021, volume2,issue 2 \\ doi:10.21926/aeer.2102007
}

Received: January 25, 2021

Accepted: April 12, 2021

Published: May 04, 2021

\begin{abstract}
Gaseous elemental mercury (GEM) was monitored in the atmosphere of a coastal site situated in the Northern Aegean Sea of Greece from August 2014 to January 2015. The selected sampling site is seldom impacted by human activities. Thus, it was possible to study the processes involved in natural terrestrial, aquatic, and atmospheric environments. The diurnal and monthly variations in the concentration of GEM as well as the factors influencing these variations were determined. The GEM concentrations were found to be in the range from 0.63 to $4.44 \mathrm{ng} \mathrm{m}^{-3}$ during data acquisition. The mean GEM concentration was about $1.04 \pm 0.30$ $\mathrm{ng} \mathrm{m}^{-3}$. Higher concentrations and variability were observed during the summer than in fall and winter. In addition, increased GEM concentrations were measured during midday. The diurnal and monthly variations in GEM were possibly affected by solar radiation, temperature, vegetation, and boundary layer height. Various peaks were observed for air masses of terrestrial origin, possibly due to the small extent of biomass burning as well as rainfall. The background concentrations of GEM in the studied coastal site were around $1.50 \mathrm{ng} \mathrm{m}^{-3}$. The sampling site is a complex environment as this coastal region has seasonal surface water in the mainland and extended areas of grassland and vegetated surfaces. All individual parameters of this area play significant roles in determining GEM concentrations.
\end{abstract}

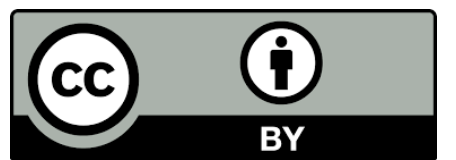

(C)2021 by the author. This is an open access article distributed under the conditions of the Creative Commons by Attribution License, which permits unrestricted use, distribution, and reproduction in any mediumor format, provided the original work is correctly cited. 


\section{Keywords}

Gaseous elemental mercury; atmospheric Hg; coastal wetlands; coastal grasslands; Aegean Sea

\section{Introduction}

Mercury is primarily found in two inorganic forms in the atmosphere, namely gaseous elemental mercury ( $\mathrm{Hg}^{0}$ or GEM) and reactive gaseous mercury ( $\mathrm{Hg}^{2+}$ or $\mathrm{RGM}$ ) such as $\mathrm{HgO}, \mathrm{HgCl}_{2}, \mathrm{HgBr}_{2}$, and $\mathrm{Hg}(\mathrm{OH})_{2}$ [1]. Small concentrations of mercury exist in organic form in the atmosphere (e.g., monomethylmercury salts, and other organometallic complexes). Elemental mercury is the most abundant form of $\mathrm{Hg}$ ( 95-99\%) in the atmosphere [2], which has low reactivity, low solubility in water, and an atmospheric lifetime of $\sim 1$ year [3]. This form is mainly removed by its oxidation to $\mathrm{Hg}^{2+}$ ions. Thus, it can be transported over long distances. $\mathrm{Hg}^{2+}$ salts are less volatile than $\mathrm{Hg}^{0}$, exhibit solubility in water, lifetimes range from a few days to weeks [4], reactive, and are rapidly removable via wet and dry deposition.

Atmospheric mercury originates from natural sources, such as volcanoes and evaporation from aquatic surfaces, in addition to anthropogenic sources, such as fossil fuel combustion, cement production, waste incineration, and other industrial processes $[5,6]$. Forest fires and re-emission from land and surface water are also important sources of $\mathrm{Hg}$. Elemental mercury is emitted from anthropogenic sources as well as natural surfaces [7]. Each of the primary sources, namely direct anthropogenic sources, natural sources, and re-emission of previously deposited anthropogenic emissions, contribute to about one-third of $\mathrm{Hg}$ in the atmosphere but with considerable uncertainties [8]. The concentration of atmospheric oxidized mercury is mainly attributed to the oxidation of elemental mercury and emission from anthropogenic sources to a limited extent [9]. The oceans are a source as well as a sink for atmospheric mercury in the context of global mercury cycling [10]. About $89 \%$ of the ocean emissions result from the re-emission of the previously deposited mercury in the ocean [10]. The emission of elemental mercury from surface water is affected by the solar radiation and temperature gradient in the air-water interface [11]. The increased solar radiation and temperature raise the evasion flux from water to the atmosphere [11].

In the previous studies conducted by the group on the biogeochemical cycles of $\mathrm{Hg}$ [12-16], a novel method for its environmental speciation was introduced [17-19]. The mercury cycle includes rapid oxidation of $\mathrm{Hg}^{0}$ to $\mathrm{Hg}^{2+}$ and $\mathrm{Hg}^{+}$intermediates and their deposition on the oceans and biosphere. This is attributed to the more rapid deposition of oxidized mercury compared to elemental mercury [20]. The cycle also involves the photochemical reduction of dissolved $\mathrm{Hg}^{2+}$ to its elemental form and the subsequent removal through volatilization [21]. The oxidation of elemental mercury by bromine, acting as the main oxidant, and other oxidants, such as chlorine, $\mathrm{O}_{3}$, and $\mathrm{OH}$, to oxidized mercury is the primary process that occurs in the marine boundary layer, polar regions, and coastal areas $[4,20,22]$. The seawater reduction of $\mathrm{Hg}^{2+}$ to $\mathrm{Hg}^{0}$ can also be the result of biotic transformations [23]. A part of $\mathrm{Hg}^{2+}$ is methylated and accumulated in the food chain [24] but also further demethylated to $\mathrm{Hg}^{0}[25]$.

In the present study, the atmospheric concentrations of gaseous elemental mercury in a coastal site in Northern Greece were determined. The main objectives of this study were (a) to determine 
the diurnal and monthly variations in GEM and (b) to explore the factors influencing these variations. In this study, the elemental mercury concentrations alone were determined using the employed instrumentation. To date, there are no other experimental investigations on the ambient mercury concentrations in the atmosphere of Greece, except for a study on the mercury emissions from a Greek volcanic area [26].

\section{Materials and Methods}

\subsection{Site Description}

The measurements were taken from August 1, 2014, to November 9, 2014, and January 12-21 2015 in the coastal area of Northeastern Greece $\left(40^{\circ} 53^{\prime} 22.47^{\prime \prime} \mathrm{N}, 24^{\circ} 51^{\prime} 0.43^{\prime \prime} \mathrm{E}\right)$ as shown in Figure 1a. The distance between the sampling site and coast was about 200 meters. The sampling site had a window toward the sea in the range of $50^{\circ}$ to $180^{\circ}$. The city of Xanthi, having 70,000 inhabitants, is situated in the North at a distance of $30 \mathrm{~km}$, and the delta of Nestos River is situated in the West at a distance of $5 \mathrm{~km}$. The larger part of the sampling site within a radius of $1 \mathrm{~km}$ consisted of grassland, which turns into a coastal wetland during winter. Furthermore, there are agricultural activities and minor industrial areas within a radius of $30 \mathrm{~km}$.

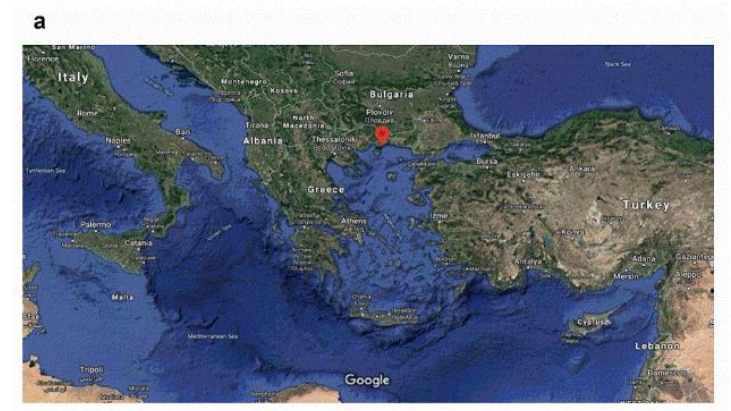

b

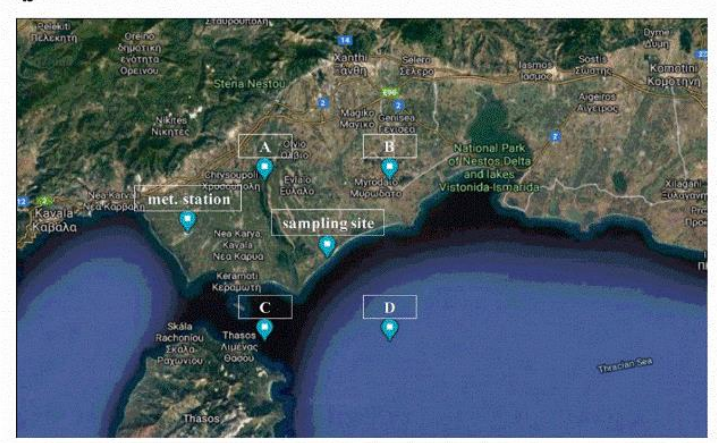

Figure 1 a) Google map illustrating the position of the sampling site among the larger part of Europe. b) Google map illustrating the sampling site surrounded by the four $0.205^{\circ} \mathrm{x} \sim 0.204^{\circ}$ grid points (A, B, C, D) whose planetary boundary layer heights (in meters) were obtained, and the HNMS meteorological station. The coordinates of the grid points are (A) lat $40.988 \mathrm{~N}$ and long $24.75 \mathrm{E},(\mathrm{B})$ lat $40.988 \mathrm{~N}$ and long $24.95 \mathrm{E},(\mathrm{C})$ lat $40.784 \mathrm{~N}$ and long $24.75 \mathrm{E},(\mathrm{D})$ lat $40.784 \mathrm{~N}$ and long $24.95 \mathrm{E}$. Our site was situated at lat $40.889 \mathrm{~N}$ and long $24.85 \mathrm{E}$. 
The sampling area was part of a protected area (Natura 2000, SCl code: GR1150010) consisting mainly of Mediterranean salt meadows (Juncetalia maritimi), Mediterranean tall humid grasslands of Molinio-Holoschoenion with tall grasses and rushes, areas covered with various plant species, coastal lagoons, and dunes. The average vegetation height in the extended sampling area was about $2 \mathrm{~m}$. The normalized difference vegetation index (NDVI) of the sampling site is presented in [27], ranging from 0.4 to 0.7 for the selected sampling period.

The Aegean Sea is a semi-closed marine system as it is situated in the Eastern Mediterranean basin. The coastal waters of the North Aegean Sea tend to accumulate the pollutants originating from the Black Sea waters, especially during summer and autumn, according to the numerical models on the dispersion and accumulation of pollutants from the Black Sea [28]. In addition, two main rivers discharge to the Thracian Sea, namely the Evros River in the East at a distance of about $100 \mathrm{~km}$ from the sampling site and the Nestos River $5 \mathrm{~km}$ due West. These rivers have their sources in Bulgaria. The Thracian Sea may be influenced by the natural and anthropogenic load of $\mathrm{Hg}$ carried by the two rivers although two earlier studies confirmed that they do not carry a large mercury load $[29,30]$.

\subsection{Sampling Instrumentation}

In the sampling site, a Tekran 2537B Mercury Vapor Analyzer (Tekran, Inc., Toronto, ON, Canada) was employed to continuously measure the GEM concentration. A six-meter long Kynar ${ }^{\circ}$ polyvinylidene fluoride (PVDF) tubing with 1/4" I.D. and 3/8" O.D. was used for sampling purposes, and the sampling inlet was placed at a height of $5 \mathrm{~m}$. The trapped mercury was adsorbed by two gold cartridges. The role of these two cartridges was reversed during sampling/adsorption processes and thermal desorption/analysis. Cold vapor atomic fluorescence spectrometry (CVAFS) was used to detect $\mathrm{Hg}^{0}$. This method detects quantities in the range from 0.10 to $2000 \mathrm{ng} \mathrm{m}^{-3}$. The sample inlet filter, a Teflon filter membrane $(0.20 \mu \mathrm{m}, 47 \mathrm{~mm}$ diameter $)$, which was used to prevent the entry from particulate matters into the measuring system was changed according to the maintenance instructions. The selected sampling time was $10 \mathrm{~min}$ at a sampling flow rate of $1 \mathrm{~L} \mathrm{~min}^{-}$ 1. The detection limit was estimated to be $\sim 0.10 \mathrm{ng} \mathrm{m}^{-3}$ [31]. The mercury analyzer attached to the sampling tubing was calibrated externally using the lab-constructed Calibration Gas Generator and a mercury permeation tube (VICI Metronics, Inc., Poulsbo, WA, USA).

The meteorological data, such as temperature, humidity, wind velocity, wind direction, and barometric pressure, were measured at $1 \mathrm{~Hz}$ in the same site, as described in the previous studies $[27,32]$. The additional meteorological data were provided by the Hellenic National Meteorological Service (HNMS). The nearest station (Figure $1 \mathrm{~b}$ ) is located at the Kavala airport of Chrysoupoli $\left(40^{\circ} 54^{\prime} 47.90^{\prime \prime} \mathrm{N}, 24^{\circ} 37^{\prime} 09.20^{\prime \prime} \mathrm{E}\right)$ at a distance of about $20 \mathrm{~km}$ from the sampling site. The HNMS station provided data on wind velocity, wind direction, temperature, humidity, barometric pressure, visibility, total cloudiness, precipitation, and hours of sunlight in the region.

\subsection{Back Trajectory Modeling}

The air mass backward trajectories were computed using the NOAA Hybrid Single-Particle Lagrangian Integrated Trajectory model [33,34] based on the Global Data Assimilation System (GDAS) meteorological data (archived from 2006 to present). The trajectories were initialized every $6 \mathrm{~h}$ at the starting heights of 100,500 , and $1500 \mathrm{~m}$. The starting location of the back trajectories 
was the sampling site. The start time of each back trajectory was selected according to the processes undergone by GEM. The back trajectories were used to identify the origin of the air masses in each peak episode, no peak episode, and minimum concentration events.

\subsection{Planetary Boundary Layer Height}

The data for the Planetary Boundary Layer (PBL) height were obtained using the NCEP Climate Forecast System Version 2 (CFSv2) [35] and treated with Matlab (MATLAB and Statistics Toolbox Release 2010b, The MathWorks, Inc., Natick, MA, USA). The selected grid was $0.205^{\circ} \mathrm{x} \sim 0.204^{\circ}$ to produce the gridded products in a $1 \mathrm{~h}$ forecast. The vertical level was defined above the ground or water surface. Four closest grid points were selected (Figure 1b), which surround the sampling site.

\section{Results and Discussion}

\subsection{Summary of GEM Concentrations}

The measurements of GEM concentrations were performed in a coastal area impacted by human activities only to a small extent. The sampling was conducted from August to November 2014 and January 2015, with a total of 14,907 GEM concentration values. In this study, the GEM concentrations ranged from 0.63 to $4.44 \mathrm{ng} \mathrm{m}^{-3}$ during the whole period of measurement with a mean concentration of $1.04 \pm 0.30 \mathrm{ng} \mathrm{m}^{-3}$. The highest concentration was measured during a night in summer with rain and a wind velocity of $12 \mathrm{~m} \mathrm{~s}^{-1}$. The lowest concentration was measured during one of the nights in October. The mean concentration of the sampling period is not a typical annual mean value as there had been no data for a whole year. The statistics of GEM concentrations and other meteorological parameters for all data are presented in Table 1. The time series of daily mean GEM concentration is presented in Figure 2, and the time series with hourly mean and maximum concentrations of each hour is given in Figure $\mathrm{S} 1$.

Table 1 Statistics of the gaseous elemental mercury (GEM) concentrations and other meteorological parameters.

\begin{tabular}{|c|c|c|c|c|c|c|c|c|}
\hline \multirow{2}{*}{$\begin{array}{c}\text { Time Period } \\
\text { Month }\end{array}$} & \multirow[b]{2}{*}{$\mathrm{n}^{\mathrm{a}}$} & \multicolumn{4}{|c|}{$\begin{array}{l}\text { Statistical Parameters of GEM } \\
\text { in } \mathrm{ng} \mathrm{m}^{-3}\end{array}$} & \multicolumn{3}{|c|}{ Meteorological Parameters } \\
\hline & & Mean \pm Std & Median & Min & Max & $\begin{array}{c}W V^{b} \\
\left(\mathrm{~m} \mathrm{~s}^{-1}\right)\end{array}$ & $\begin{array}{c}\text { Temp. }^{\mathrm{c}} \\
\left({ }^{\circ} \mathrm{C}\right)\end{array}$ & $\begin{array}{l}\mathrm{RH}^{\mathrm{d}} \\
(\%)\end{array}$ \\
\hline August 2014 & 4205 & $1.38 \pm 0.35$ & 1.31 & 0.99 & 4.44 & $\begin{array}{c}2.30 \pm \\
0.51\end{array}$ & $\begin{array}{c}24.73 \pm \\
1.50\end{array}$ & $\begin{array}{c}69.04 \pm \\
9.27\end{array}$ \\
\hline September 2014 & 3828 & $0.92 \pm 0.13$ & 0.89 & 0.67 & 2.73 & $\begin{array}{c}2.22 \pm \\
0.38\end{array}$ & $\begin{array}{c}19.91 \pm \\
3.03\end{array}$ & $\begin{array}{c}71.72 \pm \\
10.33\end{array}$ \\
\hline October 2014 & 4376 & $0.88 \pm 0.11$ & 0.86 & 0.63 & 1.73 & $\begin{array}{c}2.66 \pm \\
1.42\end{array}$ & $\begin{array}{c}15.26 \pm \\
3.15\end{array}$ & $\begin{array}{c}76.51 \pm \\
10.73\end{array}$ \\
\hline November 2014 & 1213 & $0.94 \pm 0.10$ & 0.92 & 0.73 & 1.53 & $\begin{array}{c}1.67 \pm \\
0.49\end{array}$ & $\begin{array}{c}11.85 \pm \\
2.04\end{array}$ & $\begin{array}{c}81.62 \pm \\
9.83\end{array}$ \\
\hline January 2015 & 1285 & $0.98 \pm 0.07$ & 0.97 & 0.76 & 1.78 & $\begin{array}{c}1.86 \pm \\
0.49\end{array}$ & $\begin{array}{c}5.88 \pm \\
2.59\end{array}$ & $\begin{array}{c}82.15 \pm \\
11.35\end{array}$ \\
\hline
\end{tabular}


${ }^{\mathrm{a}} \mathrm{n}$ : number of determinations, ${ }^{\mathrm{b}} \mathrm{WV}$ : wind velocity, ${ }^{\mathrm{C}}$ Temp.: ambient temperature, ${ }^{\mathrm{d}} \mathrm{RH}$ : relative humidity.

a

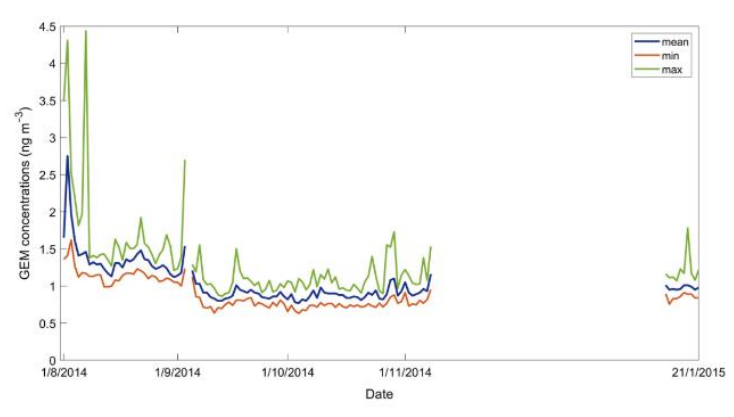

C

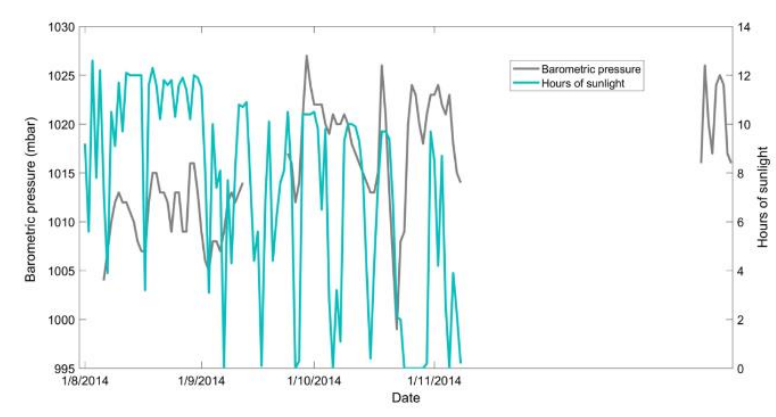

b

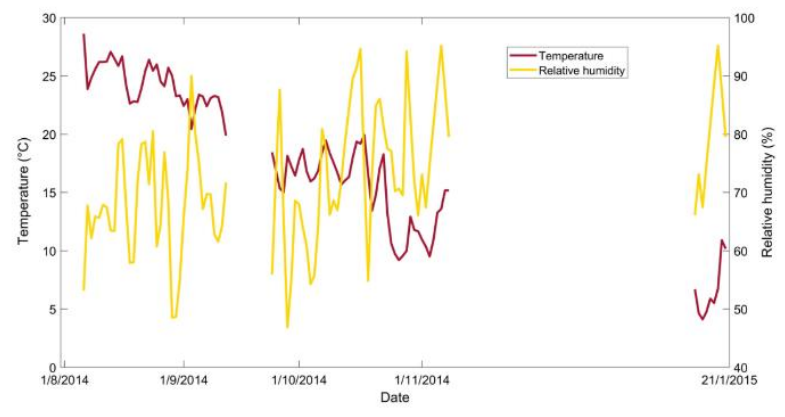

d

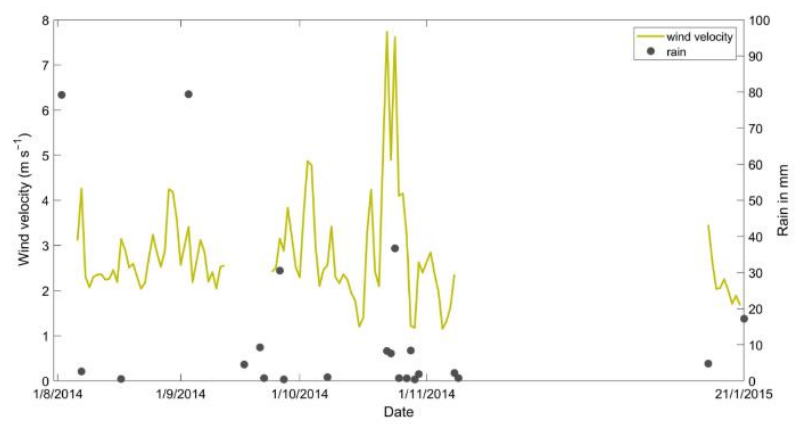

Figure 2 Time series of (a) the daily mean gaseous elemental mercury (GEM) concentrations, minimum and maximum GEM concentrations of each day, (b) temperature and relative humidity, (c) barometric pressure and hours of sunlight per day, and (d) wind velocity, along with rainy events during the months of measurements.

The level of GEM concentrations in the atmosphere may be primarily affected by the local emissions and not as much by the advection from other areas. In this case, there were no surrounding continental intensive and permanent emission sources in the sampling area, and no strong influence from coal combustion that offers remarkably high anthropogenic mercury emissions but only a few episodes, as discussed in Section 3.4. We considered as natural background GEM concentrations those values which remain at lowest level for a long duration, such as a whole day or days. In this study, days with constant low concentration, showing no fluctuations until the end of the day, were recorded. In August, all concentrations during the days and nights were greater than $1 \mathrm{ng} \mathrm{m}^{-3}$, whereas the concentrations were either below or greater than $1 \mathrm{ng} \mathrm{m}^{-3}$ for other months. The air masses with low GEM levels originated either from the sea or land. As the wind originates from the sea, the GEM concentrations were less than $1.50 \mathrm{ng} \mathrm{m}^{-3}$. For the coastal environment in the sampling area, the background concentrations were determined in the range of 0.63 to $1.50 \mathrm{ng} \mathrm{m}^{-3}$. 


\subsection{Other Studies in Literature}

According to [36], the annual median concentrations of TGM are higher in the Northern Hemisphere (between $\sim 1.40$ and $1.80 \mathrm{ng} \mathrm{m}^{-3}$ ) than in the Southern Hemisphere (from $\sim 0.80$ to $1.40 \mathrm{ng} \mathrm{m}^{-3}$ ). In the Mediterranean area, total gaseous mercury concentrations varied between 1.30 and $2.40 \mathrm{ng} \mathrm{m}^{-3}$ according to [37], and the higher values were the result of the influence of major sources. According to another study, the TGM average values extended from 0.80 to $8.71 \mathrm{ng} \mathrm{m}^{-3}$ at the coastal sites in the Mediterranean, and the overwater TGM values ranged from 0.2 to $15.7 \mathrm{ng}$ $\mathrm{m}^{-3}$ in the Eastern Mediterranean and from 0.1 to $32 \mathrm{ng} \mathrm{m}^{-3}$ in the Western Mediterranean during the Mediterranean cruises, with seasonal variations arising from minimum values during the winter and maximum values during the summer [38]. This seasonality is the opposite of that observed in Northern Europe and results from the meteorological and climatic conditions that dominate the Mediterranean Basin (i.e., warmer climate, high temperature, and strong solar radiation). In addition, the measurement sites in the literature are limited. Also, the previous studies in the literature were mainly focused on contaminated areas [39].

An example of the low levels of GEM concentration was presented in [40], where monthly median TGM concentrations in the Kejimkujik National Park and National Historic Site (Nova Scotia, Canada) were below or around $1 \mathrm{ng} \mathrm{m}^{-3}$ for a few months during 2000-2009, although the mean TGM concentration was $1.38 \pm 0.33 \mathrm{ng} \mathrm{m}^{-3}$ for all these years despite high concentrations of methylmercury observed in this area. The monthly median GEM concentrations were measured to be around or below $1 \mathrm{ng} \mathrm{m}^{-3}$ in the U.S. and Canada as well, which was reported in [41]. Various cases of monthly mean GEM concentrations around or below $1 \mathrm{ng} \mathrm{m}^{-3}$ due to the vegetation uptake in the European, North American, and Asian monitoring sites are summarized in [42].

\subsection{Diurnal and Monthly Variations in GEM Concentrations: The Contributing Factors}

\subsubsection{Diurnal Cycles}

The GEM concentration was found to be higher around midday (Figure 3), mostly in August and to a smaller extent in September and October for a short time. This result was also reported by other studies [43]. The main factors that affect the increased levels of GEM concentration around midday are the enhanced ambient temperature and solar radiation during the day that prevail especially during August, and enhance the release of $\mathrm{Hg}^{0}$ from surface water [11]. The enhanced evasion is linked to the increased photoreduction and biological activity [44]. The diurnal patterns of temperature and wind velocity (Figure 3) predominantly during August follow similar variations as that of GEM concentrations. The correlation of the August GEM concentrations with ambient temperature was strong, as shown in Table S1. In addition, the correlation with wind velocity was moderate and with relative humidity was negative and also significant. According to the literature the seawater-to-air mercury vapor transfer is facilitated by the strong water-to-air temperature gradient and moderate wind speed [45]. It is obvious in Table S1 that the effects of wind velocity, temperature, and relative humidity on the diurnal concentration variation of August are significant. This unique pattern was not observed in any of the other months. It is worth mentioning that November and January seemed to have similar patterns in their diurnal concentration variations, which showed a moderate negative correlation of GEM concentrations with temperature and moderate positive correlation with relative humidity. According to [44], factors such as surface and 
local emissions, $\mathrm{Hg}$ photochemistry, boundary layer dynamics, dry deposition, and sequestering by dew affect the diurnal patterns.

a

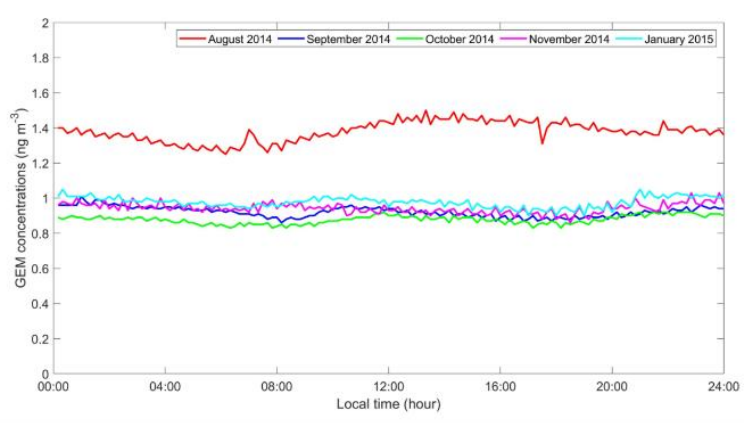

C

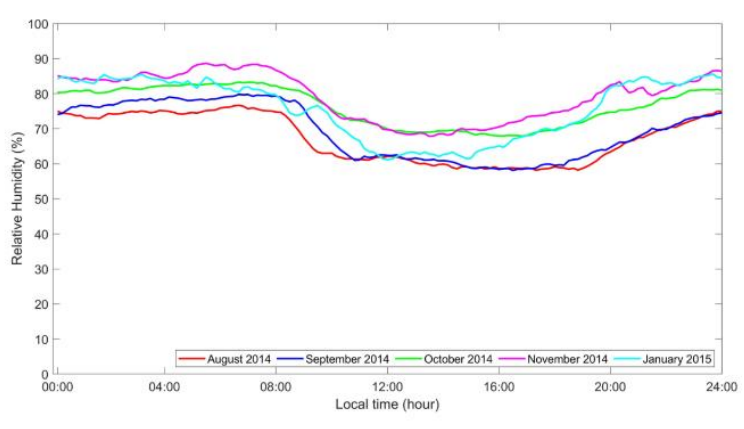

b

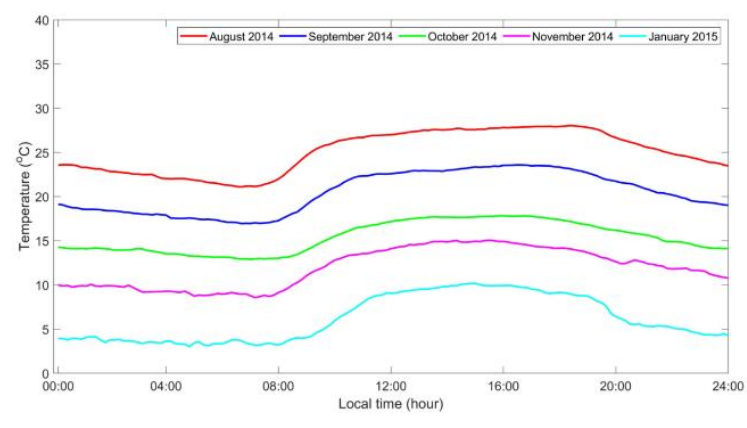

d

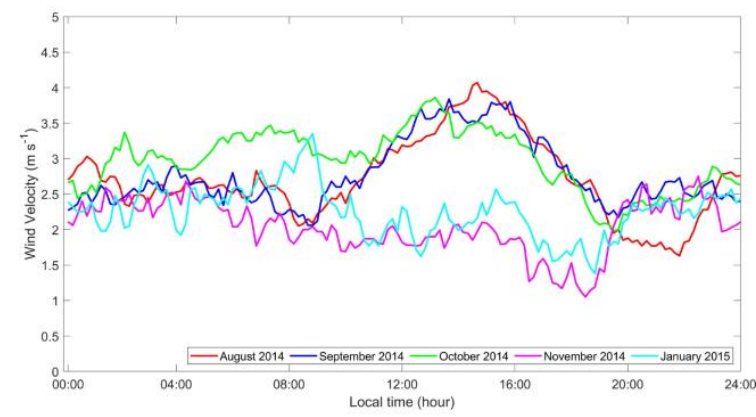

Figure 3 Plots for the diurnal variations in (a) gaseous elemental mercury (GEM) concentrations, (b) temperature, (c) relative humidity, and (d) wind velocity.

\subsubsection{Monthly Variations}

A high level of GEM concentration was observed during August 2014, whereas a lower level was found during September, October, November 2014, and January 2015, which are in agreement with the patterns observed in other western Mediterranean sites [46]. This is mainly explained by the high solar radiation, humidity, and temperature in the Mediterranean Basin during summer, resulting in higher emission of $\mathrm{Hg}$ from the sea surface [37]. During summer, the depth of the thermocline and temperature gradient in the surface water increased from the Western to the Eastern Basin of the Mediterranean [37]. The high water temperature may affect the biotic and abiotic processes that contribute to the evasion of $\mathrm{Hg}$ to the atmosphere [11]. In addition, the release of $\mathrm{Hg}^{0}$ from the surface water is facilitated by solar radiation [11]. According to [45], the coastal waters and especially shallow waters act as significant sources of gaseous mercury during summer. The vegetated surfaces may also contribute to the variations, as discussed further in 3.3.4.

\subsubsection{The Role of the Coastal Area}

The photochemical gas-phase oxidation of $\mathrm{Hg}^{0}$ to $\mathrm{Hg}^{\prime \prime}$ affects the level of GEM concentration. The $\mathrm{O}_{3}$ concentrations in the Mediterranean coastal areas are higher during summer than winter, causing a strong atmospheric oxidative potential. Additionally, according to the literature $\mathrm{Hg}^{0}$ is oxidized by bromine $(\mathrm{Br})$ to form $\mathrm{Hg}^{\prime \prime}$, and this oxidation rate decreases with higher air temperatures 
[47], increasing the GEM during summer. The atomic bromine ( $\mathrm{Br}$ ) from the marine organobromine compounds emitted by phytoplankton is the main atmospheric $\mathrm{Hg}^{0}$ oxidant that contributes to $97 \%$ of total oxidation, resulting in a chemical lifetime of 2.7 months for the tropospheric $\mathrm{Hg}^{0}$ against oxidation [48]. The fact that there was no obvious decrease in GEM during summer was further explained by the simultaneous evasion of $\mathrm{Hg}$ by the surface water to a greater extent than the deposition or transfer of $\mathrm{Hg}$ with the air masses. It is a fact that the total evasion of $\mathrm{Hg}$ in the Mediterranean Basin is far greater than the total deposition [49]. All photochemical processes of gas-phase oxidation and evasion of GEM from the surface water probably enhanced the GEM concentration in the coastal area, mainly during the summer, but keeping the GEM concentration at low levels during the other months.

\subsubsection{The Role of Vegetation}

Another factor that can strongly affect both the diurnal and seasonal variations in GEM is the vegetation. Enhanced diurnal GEM concentration variation was observed for high vegetation photosynthetic activity [42]. A possible reason for the increase in GEM concentration during midday could be attributed to the enhanced daytime photochemical $\mathrm{Hg}^{0}$ re-emission from the foliage and soils under the presence of solar radiation and other influencing parameters, such as soil water content, temperature, atmospheric oxidants, and atmospheric $\mathrm{Hg}$ concentrations [50].

Grassland covers a major portion of the sampling site (see Section 2.1), which is largely covered by vegetated surfaces. The characteristics of the sampling area change during autumn and winter as a part of the grassland is flooded with brackish water resulting in a coastal wetland. These characteristics of the sampling site may play a key role in determining the GEM concentration and its monthly variation. Low GEM concentration was observed during autumn and winter. According to the literature the dry deposition of GEM on vegetated surfaces and wetlands is stronger and more significant than that over non-vegetated surfaces (e.g., bare soil) and water bodies that are very low, suggesting that the vegetation acts as a sink for atmospheric GEM [51]. In the same previously mentioned study, it is also noted that the ecosystem is one of the largest sinks for atmospheric $\mathrm{Hg}$, as the uptake of GEM through the stomata of the plant leaves is significant, although less known as a contributing process [52]. In [53], it is emphasized that Juncus maritimus, which abundantly exists in the sampling area, acts as a sink, even in the case of a mercury-contaminated salt marsh.

\subsubsection{Temperature, Duration of Sunlight, and Humidity}

The calculation of the Pearson correlation coefficients ( $r$ ) between GEM concentrations and meteorological parameters showed a moderate linear relationship with the temperature equal to $0.53(p=0)$ and a minor correlation with the duration of sunlight equivalent to $0.28(p=0.0046)$. The low correlation between the GEM concentration and duration of sunlight does not exactly mean that the contribution of the sun is negligible. The GEM concentrations were high during cloudy days corresponding to low boundary layer height. During August, the sunny days and hours were more than in the other months. Combined with the high temperatures reported throughout August, it may explain the increased GEM concentration. The solar radiation and temperature contributed to the enhanced GEM concentration as the air masses originated either from the sea or the vegetated surfaces but did not exhibit any peaks. 
On the arrival of September, the hours of sunlight decreased remarkably, and the temperature, as well as the GEM concentrations, decreased, as seen from Figure 2. Furthermore, the relative humidity increased from summer to winter. The presence of water in the atmosphere may facilitate the oxidation of $\mathrm{Hg}^{0}[4,54]$ and, therefore, the removal of mercury from the atmosphere, in addition to the unfavorable circumstances for the evasion of mercury from the water surface, such as strong solar radiation and high temperature. According to [51], low $\mathrm{O}_{3}$ concentration and high relative humidity $(\mathrm{RH})$ may enhance the uptake of GEM by foliage, especially at night.

\subsubsection{Boundary Layer Height}

The diurnal and seasonal variations in GEM appear to be influenced by the boundary layer processes, and so far, the studies reported different patterns for the diurnal variation [55]. As seen from Figure 4, the terrestrial boundary layer height decreased with months until the lowest level was attained in January. The increased solar radiation, mainly during summer, enhances the turbulence and increases the depth of the boundary layer. The lowest nocturnal heights were observed during November and January. The marine boundary layer (MBL) height was increased in September and its lowest level was noticed in August and January. According to the literature, there is a difference in the boundary layer heights in the coastal sites, where the land meet the water surfaces and the transition zone between the different boundary layers is complicated [56]. In addition, in the same previously mentioned study, the atmospheric phenomenon of the land-sea breeze system influences the coastal circulation and mixing, which, in turn, affects the diurnal variation in GEM concentration [56]. 

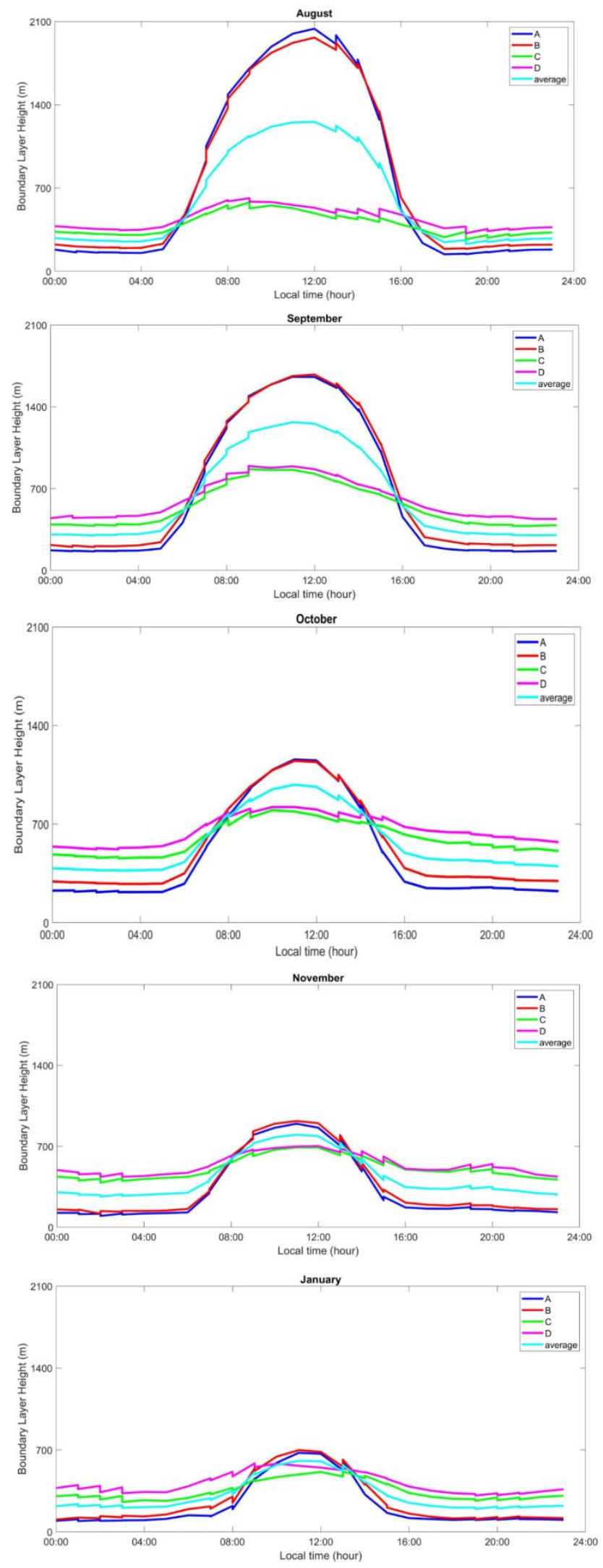

Figure 4 Diurnal mean variations in the Boundary Layer Height of each month for the four grid points indicated in Figure $1 \mathrm{~b}$ and their averages. 
The MBL height was predominantly low in the range of 100 to $200 \mathrm{~m}$ during midday corresponding to elevated GEM concentration. In these mentioned cases with increased concentration during midday, the boundary layer height above the ground for the midday duration was also low, with depth lower than this observed the other days. The concentration increased in a smaller volume of air over a shallow boundary layer. Low MBL heights were observed on the midday of August than any other months. The highest MBL heights were observed at the midday of September. The sharp change in the MBL from August to September may explain the decrease in the GEM concentration during these months.

In the case of a shallow nocturnal planetary boundary layer (PBL) observed during the cold season, the transport of air masses and vertical mixing are limited, and the plant uptake of GEM contributes to its depletion. The role of vegetation described in Section 3.3.4 and the lower boundary layer height along with other contributing factors mentioned in previous paragraphs contribute to the low concentration observed during the cold season instead of summer. In contrast, the slightly higher concentration observed during November and January as opposed to October may be explained by the combination of low boundary layer height and domestic combustion for heating purposes, as mentioned in 3.4.3. This was more obvious as the concentration increased after 20:00 (Figure 3a) under intense heating demands. In addition, the moderate negative correlation of diurnal variations between GEM concentrations and temperature reinforces the fact that the lower temperatures lead to domestic combustion for heating and subsequently to increased GEM concentrations.

\subsection{Factors Affecting the Maximum GEM Concentrations}

The possible factors that contribute to the occurrence of maximum concentrations are presented in the following sections. Most of the peaks of GEM concentration were observed in the absence of sunlight, with high cloudiness or rain, and in some cases at night.

\subsubsection{Wind Direction and Origin of Air Masses}

The meteorological conditions during the sampling periods are presented in Table 1 and Figure 2. During the campaign, the prevailing wind direction was from the Northeast, i.e., the mainland. The back-trajectory analysis (Figures S2, S3, and S4) and rose plot in Figure 5 showed that the majority of high mercury concentrations were measured as the air masses originated from the land. The backward trajectories presented in Figures S2, S3, and S4 refer to the first three maximum GEM concentrations dated $1 / 8 / 2014,2 / 8 / 2014$, and $7 / 8 / 2014$, respectively, which was the common pattern observed for high concentrations. The concentrations of these peaks were $3.49,4.31$, and $4.44 \mathrm{ng} \mathrm{m}^{-3}$, respectively. The concentration corresponding to the second peak $\left(4.31 \mathrm{ng} \mathrm{m}^{-3}\right)$ was sampled under the rainfall of $79.2 \mathrm{~mm}$ and that of the third peak $\left(4.44 \mathrm{ng} \mathrm{m}^{-3}\right)$ was measured under the rainfall of $2.6 \mathrm{~mm}$. High GEM concentrations were also observed as the air masses came from the sea and a habitable island, but only for a minor percentage of the cases. 


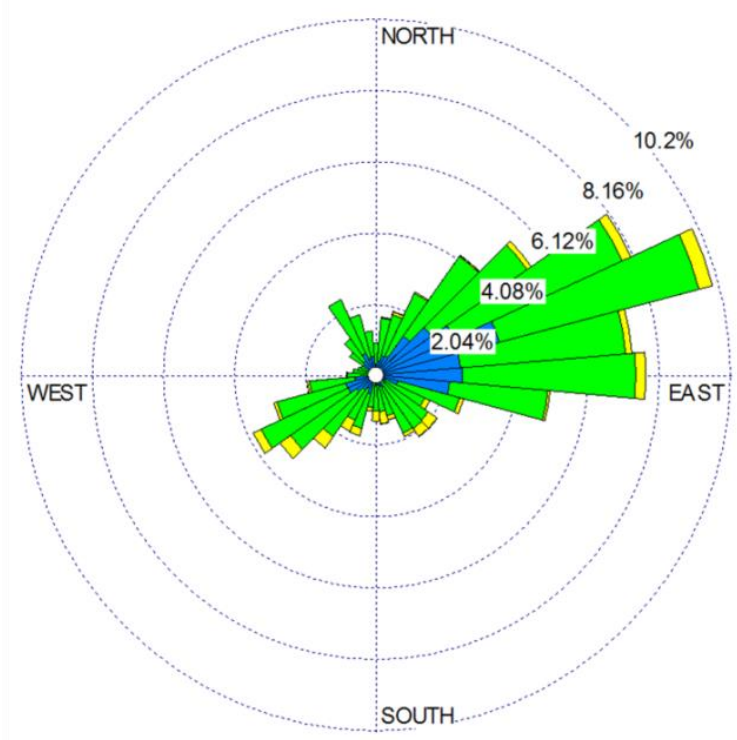

Figure 5 Gaseous elemental mercury (GEM) rose plot for GEM concentrations and the measurements of wind direction in the sampling site. The GEM concentrations are divided into the following classes: Blue for 0-1 $\mathrm{ng} \mathrm{m}^{-3}$, green for 1-1.5 $\mathrm{ng} \mathrm{m}^{-3}$, and yellow for concentrations greater than $1.5 \mathrm{ng} \mathrm{m}^{-3}$.

\subsubsection{Rain Events}

The rain events enhanced the mercury concentration, also contributing to a few peaks, as presented in Figure 2 and supported by Figure S1. This could be attributed to the GEM evasion from the soil. According to [57], the emission of mercury from the local anthropogenic sources are further removed by precipitation. In addition, the boundary layer height above the ground was lower than the marine boundary layer height during the rain events and periods corresponding to the observed peaks. In August, the two highest GEM concentrations were measured during the rainy days, where the air masses originated from the land (see Section 3.4.1 and Figures S2, S3, and S4). However, not all rain events contributing to the peaks corresponding to the air masses originating from the land. The emission of $\mathrm{Hg}^{0}$ from the soil was probably enhanced after the transition of the soil from the dry to the wet situation due to rain events $[58,59]$. The GEM emissions from the soil were also facilitated by the incoming solar radiation and soil temperature [60].

\subsubsection{Anthropogenic Emissions}

A few of the GEM concentration peaks occurred due to anthropogenic $\mathrm{Hg}$ emissions, such as fires on the beach in the summer and a small extent of biomass burning for agricultural land clearing in September and October. During the cold season, the GEM concentrations were slightly higher than those in September and October, probably due to domestic combustion for heating purposes in the nearby villages and cities, as seen in Figure 2 [61]. 


\section{Conclusions}

The strong diurnal and monthly variations in the GEM concentration were demonstrated and the possible contributing factors were investigated in this study. The main factors contributing to the increased levels of GEM concentration during midday, mainly in August, were the high temperature and strong solar radiation. The above parameters and other influencing conditions possibly enhanced the release of $\mathrm{Hg}^{0}$ from the surface water, vegetation, and soils. These processes and the elevated number of hours of sunlight in August compared to the other months further explained the increased GEM concentrations prevailing in summer. The difference in the level of GEM concentration between August and other months may be further explained by the boundary layer height. Furthermore, the $\mathrm{Hg}$ photochemistry in the coastal area and evasion of GEM from the surface water increased the GEM concentrations mainly during summer but reduced the GEM concentrations during the cold season. The GEM concentrations in the cold season were slightly higher than those in September and October, probably due to domestic combustion for heating purposes and shallow boundary layer.

Solar radiation and temperature influence the enhanced level of GEM concentration, as the air masses originated either from the sea or vegetated surfaces but did not exhibit any peaks. Various GEM concentration peaks were observed for the air masses of terrestrial origin, which was attributed to anthropogenic emissions, such as biomass burning and rain. The air masses corresponding to low GEM concentrations were also found to originate either from the sea or land.

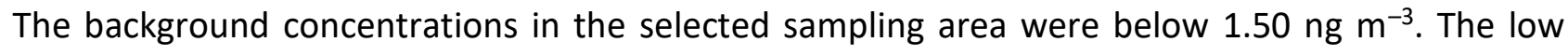
levels of GEM concentrations measured during the entire sampling period and especially during fall and winter, compared to those reported in the literature on the Mediterranean and Northern Hemisphere, are attributed to the low anthropogenic influence on the site, meteorological parameters, special characteristics of the site, and the role of the vegetated surfaces.

\section{Acknowledgments}

Ph.D. thesis of Christiana Polyzou was internally funded by university funds.

\section{Additional Materials (if any)}

The following additional materials are uploaded at the page of this paper.

1. Figure S1: Time series of mean and maximum gaseous elemental mercury (GEM) concentrations per hour.

2. Table S1: Pearson correlation coefficients and $p$-values of diurnal variations between GEM concentrations and meteorological parameters.

3. Figure S2: Backward trajectories for the date 1/8/2014.

4. Figure S3: Backward trajectories for the date $2 / 8 / 2014$.

5. Figure S4: Backward trajectories for the date 7/8/2014. 


\section{Author Contributions}

Christiana Polyzou carried out the field measurements, data treatment, data analyses, data interpretation and authorship. Spyridon Rapsomanikis and Glykeria Loupa provided data treatment, data analyses, data interpretation, authorship and editing of the publication.

\section{Funding}

This research received no external funding.

\section{Competing Interests}

The authors have declared that no competing interests exist.

\section{References}

1. Lin CJ, Pehkonen SO. The chemistry of atmospheric mercury: A review. Atmos Environ. 1999; 33: 2067-2079.

2. Gustin MS. Exchange of mercury between the atmosphere and terrestrial ecosystems. In Environmental chemistry and toxicology of mercury. Hoboken, NJ, USA: Wiley; 2011.

3. Slemr F, Schuster G, Seiler W. Distribution, speciation, and budget of atmospheric mercury. J Atmospheric Chem. 1985; 3: 407-434.

4. Lindqvist O, Rodhe H. Atmospheric mercury-A review*. Tellus B. 1985; 37B: 136-159.

5. Pirrone N, Costa P, Pacyna JM, Ferrara R. Mercury emissions to the atmosphere from natural and anthropogenic sources in the Mediterranean region. Atmos Environ. 2001; 35: 2997-3006.

6. Lynam MM, Dvonch JT, Hall NL, Morishita M, Barres JA. Trace elements and major ions in atmospheric wet and dry deposition across central Illinois, USA. Air Qual Atmosphere Health. 2015; 8: 135-147.

7. Pirrone N, Cinnirella S, Feng X, Finkelman RB, Friedli HR, Leaner J, et al. Global mercury emissions to the atmosphere from anthropogenic and natural sources. Atmospheric Chem Phys. 2010; 10: 5951-5964.

8. Lyman SN, Cheng I, Gratz LE, Weiss-Penzias P, Zhang L. An updated review of atmospheric mercury. Sci Total Environ. 2020; 707: 135575.

9. Driscoll CT, Mason RP, Chan HM, Jacob DJ, Pirrone N. Mercury as a global pollutant: Sources, pathways, and effects. Environ Sci Technol. 2013; 47: 4967-4983.

10. Strode SA, Jaeglé L, Selin NE, Jacob DJ, Park RJ, Yantosca RM, et al. Air-sea exchange in the global mercury cycle. Global Biogeochem Cycles. 2007; 21: GB1017.

11. Ferrara R, Mazzolai B, Lanzillotta E, Nucaro E, Pirrone N. Temporal trends in gaseous mercury evasion from the mediterranean seawaters. Sci Total Environ. 2000; 259: 183-190.

12. Rapsomanikis S, Weber JH. Methyl transfer reactions of environmental significance involving naturally occurring and synthetic reagents. Organomet Compd Environ. 1986;279-307.

13. Harrison RM, Rapsomanikis S. Environmental analysis using chromatography interfaced with atomic spectroscopy. Chichester: E. Horwood; 1989. 
14. Rapsomanikis S, Craig PJ. Speciation of mercury and methylmercury compounds in aqueous samples by chromatography-atomic absorption spectrometry after ethylation with sodium tetraethylborate. Anal Chim Acta. 1991; 248: 563-567.

15. Fischer R, Rapsomanikis $S$, Andreae MO. Determination of methylmercury in fish samples using GC/AA and sodium tetraethylborate derivatization. Anal Chem. 1993; 65: 763-766.

16. Fischer RG, Rapsomanikis S, Andreae MO, Baldi F. Bioaccumulation of methylmercury and transformation of inorganic mercury by macrofungi. Environ Sci Technol. 1995; 29: 993-999.

17. D'Ulivo A, Rapsomanikis S. Improvements in the atomic fluorescence detection of mercury. Anal Lett. 1997; 30: 2109-2122.

18. Rapsomanikis S, Donard OF, Weber JH. Speciation of lead and methyllead ions in water by chromatography/atomic absorption spectrometry after ethylation with sodium tetraethylborate. Anal Chem. 1986; 58: 35-38.

19. Rapsomanikis S. Derivatization by ethylation with sodium tetraethylborate for the speciation of metals and organometallics in environmental samples. A review. Analyst. 1994; 119: 1429-1439.

20. Steffen A, Douglas T, Amyot M, Ariya P, Aspmo K, Berg T, et al. A synthesis of atmospheric mercury depletion event chemistry in the atmosphere and snow. Atmospheric Chem Phys. 2008; 8: 1445-1482.

21. Amyot M, Gill GA, Morel FMM. Production and loss of dissolved gaseous mercury in coastal seawater. Environ Sci Technol. 1997; 31: 3606-3611.

22. Moore CW, Obrist D, Luria M. Atmospheric mercury depletion events at the Dead Sea: Spatial and temporal aspects. Atmos Environ. 2013; 69: 231-239.

23. Mason RP, Morel FMM, Hemond HF. The role of microorganisms in elemental mercury formation in natural waters. Water Air Soil Pollut. 1995; 80: 775-787.

24. Horvat M, Kotnik J, Logar M, Fajon V, Zvonarić T, Pirrone N. Speciation of mercury in surface and deep-sea waters in the Mediterranean Sea. Atmos Environ. 2003; 37: 93-108.

25. Mason RP, Fitzgerald WF. The distribution and biogeochemical cycling of mercury in the equatorial Pacific Ocean. Deep Sea Res Part I Oceanogr Res Pap. 1993; 40: 1897-1924.

26. Bagnato E, Tamburello G, Aiuppa A, Sprovieri M, Vougioukalakis GE, Parks M. Mercury emissions from soils and fumaroles of Nea Kameni volcanic centre, Santorini (Greece). Geochem J. 2013; 47: 437-450.

27. Trepekli A, Loupa G, Rapsomanikis S. Seasonal evapotranspiration, energy fluxes and turbulence variance characteristics of a Mediterranean coastal grassland. Agric For Meteorol. 2016; 226227: 13-27.

28. Kopasakis KI, Georgoulas AN, Angelidis PB, Kotsovinos NE. Numerical modeling of the long-term transport, dispersion, and accumulation of Black Sea pollutants into the north Aegean coastal waters. Estuaries Coast. 2012; 35: 1530-1550.

29. Christoforidis A, Stamatis N, Schmieder K, Tsachalidis E. Organochlorine and mercury contamination in fish tissues from the River Nestos, Greece. Chemosphere. 2008; 70: 694-702.

30. Lazos ES, Aggelousis G, Alexakis A. Metal and proximate composition of the edible portion of 11 freshwater fish species. J Food Compos Anal. 1989; 2: 371-381.

31. Model 2537X CVAFS Automated Mercury Analyzer. Tekran Instrum Corp. https://www.tekran.com/products/ambient-air/tekran-model-2537-cvafs-automatedmercury-analyzer/(accessed March 30, 2020). 
32. Polyzou C, Loupa G, Trepekli A, Rapsomanikis S. Fluxes of gaseous elemental mercury on a mediterranean coastal grassland. Atmosphere. 2019; 10: 485.

33. Stein AF, Draxler RR, Rolph GD, Stunder BJB, Cohen MD, Ngan F. NOAA's HYSPLIT atmospheric transport and dispersion modeling system. Bull Am Meteorol Soc. 2015; 96: 2059-2077.

34. Rolph G, Stein A, Stunder B. Real-time environmental applications and display system: Ready. Environ Model Softw. 2017; 95: 210-228.

35. Saha S, Moorthi S, Wu X, Wang J, Nadiga S, Tripp P, et al. The NCEP climate forecast system version 2. J Clim. 2014; 27: 2185-2208.

36. Slemr F, Brunke E-G, Ebinghaus R, Kuss J. Worldwide trend of atmospheric mercury since 1995. Atmospheric Chem Phys. 2011; 11: 4779-4787.

37. Kotnik J, Sprovieri F, Ogrinc N, Horvat M, Pirrone N. Mercury in the mediterranean, part I: Spatial and temporal trends. Environ Sci Pollut Res. 2014; 21: 4063-4080.

38. Sprovieri F, Pirrone N, Ebinghaus R, Kock H, Dommergue A. A review of worldwide atmospheric mercury measurements. Atmos Chem Phys. 2010; 10: 8245-8265.

39. Floreani F, Acquavita A, Petranich E, Covelli S. Diurnal fluxes of gaseous elemental mercury from the water-air interface in coastal environments of the northern Adriatic Sea. Sci Total Environ. 2019; 668: 925-935.

40. Cole AS, Steffen A, Pfaffhuber KA, Berg T, Pilote M, Poissant L, et al. Ten-year trends of atmospheric mercury in the high Arctic compared to Canadian sub-arctic and mid-latitude sites. Atmos Chem Phys. 2013; 13: 1535-1545.

41. Weiss-Penzias PS, Gay DA, Brigham ME, Parsons MT, Gustin MS, terSchure A. Trends in mercury wet deposition and mercury air concentrations across the U.S. and Canada. Sci Total Environ. 2016; 568: 546-556.

42. Jiskra M, Sonke JE, Obrist D, Bieser J, Ebinghaus R, Myhre CL, et al. A vegetation control on seasonal variations in global atmospheric mercury concentrations. Nat Geosci. 2018; 11: 244250.

43. Angot $H$, Magand $O$, Helmig D, Ricaud $P$, Quennehen $B$, Gallée $H$, et al. New insights into the atmospheric mercury cycling in central Antarctica and implications on a continental scale. Atmos Chem Phys. 2016; 16: 8249-8264.

44. Mao H, Cheng I, Zhang L. Current understanding of the driving mechanisms for spatiotemporal variations of atmospheric speciated mercury: A review. Atmos Chem Phys. 2016; 16: 1289712924.

45. Marks R, Bełdowska M. Air-sea exchange of mercury vapour over the gulf of Gdańsk and southern Baltic Sea. J Mar Syst. 2001; 27: 315-324.

46. Wängberg I, Munthe J, Amouroux D, Andersson ME, Fajon V, Ferrara R, et al. Atmospheric mercury at mediterranean coastal stations. Environ Fluid Mech. 2008; 8: 101-116.

47. Zhang $\mathrm{H}$, Holmes $\mathrm{CD}, \mathrm{Wu} \mathrm{S}$. Impacts of changes in climate, land use and land cover on atmospheric mercury. Atmos Environ. 2016; 141: 230-244.

48. Horowitz HM, Jacob DJ, Zhang Y, Dibble TS, Slemr F, Amos HM, et al. A new mechanism for atmospheric mercury redox chemistry: Implications for the global mercury budget. Atmos Chem Phys. 2017; 17: 6353-6371.

49. Hedgecock IM, Pirrone N, Trunfio GA, Sprovieri F. Integrated mercury cycling, transport, and air-water exchange (MECAWEx) model. J Geophys Res Atmos. 2006; 111: 13. 
50. Gustin MS, Engle M, Ericksen J, Lyman S, Stamenkovic J, Xin M. Mercury exchange between the atmosphere and low mercury containing substrates. Apply Geochemistry. 2006; 21: 1913-1923.

51. Fu X, Zhu W, Zhang H, Sommar J, Yu B, Yang X, et al. Depletion of atmospheric gaseous elemental mercury by plant uptake at Mt. Changbai, Northeast China. Atmos Chem Phys. 2016; 16: 12861-12873.

52. Outridge PM, Mason RP, Wang F, Guerrero S, Heimbürger-Boavida LE. Updated global and oceanic mercury budgets for the united nations global mercury assessment 2018. Environ Sci Technol. 2018; 52: 11466-11477.

53. Figueira E, Freitas R, Pereira E, Duarte A. Mercury uptake and allocation in Juncus maritimus: Implications for phytoremediation and restoration of a mercury contaminated salt marsh. J Environ Monit. 2012; 14: 2181-2188.

54. Poissant L. Field observations of total gaseous mercury behaviour: Interactions with ozone concentration and water vapour mixing ratio in air at a rural site. Water Air Soil Pollut. 1997; 97: 341-353.

55. Nair US, Wu Y, Walters J, Jansen J, Edgerton ES. Diurnal and seasonal variation of mercury species at coastal-suburban, urban, and rural sites in the southeastern United States. Atmos Environ. 2012; 47: 499-508.

56. Ren X, Luke WT, Kelley P, Cohen MD, Olson ML, Walker J, et al. Long-term observations of atmospheric speciated mercury at a coastal site in the northern gulf of Mexico during 20072018. Atmosphere. 2020; 11: 268.

57. Lynam M, Dvonch JT, Barres J, Percy K. Atmospheric wet deposition of mercury to the Athabasca Oil Sands Region, Alberta, Canada. Air Qual Atmos Health. 2018; 11: 83-93.

58. Poissant L, Pilote $M$, Casimir A. Mercury flux measurements in a naturally enriched area: Correlation with environmental conditions during the Nevada Study and Tests of the Release of Mercury From Soils (STORMS). J Geophys Res Atmos. 1999; 104: 21845-21857.

59. Song $X$, Heyst BV. Volatilization of mercury from soils in response to simulated precipitation. Atmos Environ. 2005; 39: 7494-7505.

60. Moore C, Carpi A. Mechanisms of the emission of mercury from soil: Role of UV radiation. J Geophys Res Atmos. 2005; 110: D24302.

61. Zhang $\mathrm{W}$, Tong $\mathrm{Y}, \mathrm{Hu} \mathrm{D}, \mathrm{Ou} \mathrm{L}, \mathrm{Wang} \mathrm{X}$. Characterization of atmospheric mercury concentrations along an urban-rural gradient using a newly developed passive sampler. Atmos Environ. 2012; 47: 26-32. 


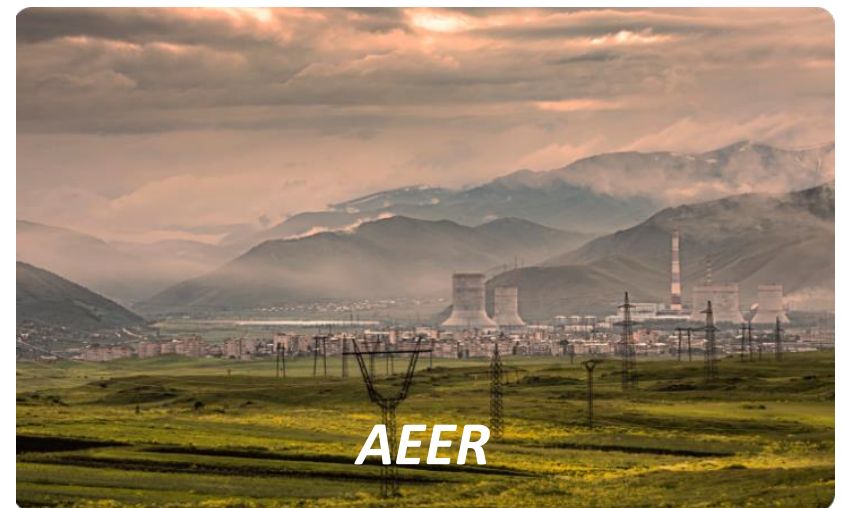

Enjoy $A E E R$ by:

1. Submitting a manuscript

2. Joining in volunteer reviewer bank

3. Joining Editorial Board

4. Guest editing a special issue

For more details, please visit:

http://www.lidsen.com/journals/aeer 